ROBERT W. CRANDALL

Brookings Institution

\title{
The Effects of \\ U.S. Trade Protection \\ for Autos and Steel
}

THE ROUGHLy 60 percent appreciation in the real value of the U.S. dollar between 1979 and 1985 created an environment that was increasingly conducive to protectionist politics in the United States. Automobile and steel quotas were imposed. A textile quota bill was passed in the House of Representatives. Motorcycles were subjected to quotas and tariffs. And pressures mounted for protection of the semiconductor and telecommunications equipment markets.

The 1981 voluntary export restraint agreement with Japan on automobiles marked the first overt attempt to protect the U.S. automobile industry from imports since World War II. The 1984 steel voluntary restraint agreements, on the other hand, represent the third episode in protection for the U.S. steel industry in two decades. The first steel restraints began in 1969 and lasted until 1974. Trigger prices were imposed in 1978 and extended, erratically, into 1982. The current steel restraints have been implemented with twenty-five major steel exporting countries. ${ }^{1}$

Each of these exercises in trade restraint has been advanced as "temporary," designed to provide the U.S. producers with breathing room to adjust to the changes in world market conditions. ${ }^{2}$ But have

1. A number of steel exporters, including Canada, Taiwan, Argentina, and Sweden, remain outside the formal voluntary agreement although implicit understandings may exist with some of them. Altogether, there are twenty-five countries exporting steel to the United States without a formal agreement.

2. For a review of the effects of past attempts to provide industries with breathing room through temporary trade protection, see Robert Z. Lawrence and Paula R. DeMasi, 
they been successful in achieving this goal? This report seeks to provide at least a partial answer to that question, beginning with an examination of the effectiveness of the restraints in increasing domestic prices and output.

\section{Restraining Steel and Automobile Imports}

Under the General Agreement on Tariffs and Trade, countries are more likely to use quotas or voluntary restraint agreements than tariffs to protect favored or troubled industries. Country-by-country agreements substitute for formal tariff increases that could not be imposed unilaterally under the GATT.

Because of two major differences in the steel and automobile industries, voluntary restraint agreements are likely to have quite different results in the two industries. First, steel is a producers' good while automobiles are finished consumer durables. Restrictions on steel imports unaccompanied by restrictions on fabricated products made from steel are likely to induce a substitution of machinery, equipment, and vehicle imports for steel. Without a "multimetal agreement," therefore, steel quotas are likely to be relatively ineffective in the long run. Automobiles, on the other hand, have few ready substitutes other than cars already on the road. Thus, universal automobile quotas are likely to be more effective than universal steel quotas.

Second, steel is an almost ubiquitous industrial product while automobile production is heavily concentrated in North America, Europe, and Japan. In the past decade, moreover, the Japanese have vaulted ahead of the rest of the world, particularly in smaller cars. As a result, import restraints aimed solely at Japanese automobiles can be quite effective in Europe or in the United States because there are no ready substitutes for them from other parts of the world. Implicit quotas on Japanese cars in Europe and explicit quotas on Japanese automobile exports to the United States have not induced large diversions of exports in either direction across the North Atlantic. On the other hand, quotas

\footnotetext{
"Do Industries with a Self-Identified Loss of Comparative Advantage Ever Adjust?" in Gary C. Hufbauer and Howard F. Rosen, eds., Domestic Adjustment and International Trade (Washington, D.C.: Institute for International Economics, forthcoming).
} 
on steel from a limited number of steel exporters simply induce an expansion of exports from other countries. There are more than a score of major steel exporters and perhaps another twenty to thirty who can increase their exports to the United States when others are restrained. Limiting steel imports from countries in the European Community (EC) and from Japan will predictably increase imports from Brazil, Taiwan, or Canada. ${ }^{3}$

For these reasons, one would expect restraints on Japanese automobiles to be far more effective than those on steel, and in fact they have been.

\section{The Effectiveness of Steel Import Restraints}

The steel industry restraints date from the closing days of the Johnson administration. Quotas were negotiated first with Japanese, then with European, producers. The limitations on exports to the United States became effective in 1969 and were extended to 1974 , but they appear to have been binding only in 1971-72 for most products. Earlier research showed that these limits raised U.S. steel prices 1.2 to 3.5 percent in $1971-72 .{ }^{4}$

The next episode of U.S. steel protection involved trigger prices, or a floor under import prices. Trigger prices, set equal to the estimated costs of production in Japan plus importation costs, were in effect in $1978-80$ and then sporadically in 1981-82. The trigger price program was launched during a period of a depreciating U.S. dollar; hence, it had only a limited effect upon prices in the early stages, raising U.S. producer prices about 1 percent in 1979.5

As the U.S. dollar rose in 1980, U.S. producers threatened and then actually filed a number of trade suits against steel exporters. These suits were suspended, leading to a reimposition of the trigger prices, followed

3. Diversion of a homogeneous producers' good can also occur through third countries. A small amount of steel is currently exported to the United States by a number of countries with no steel mills. Such evasion of the automobile restraint agreement would obviously be impossible because the origin of a Toyota or Nissan cannot be concealed.

4. Robert W. Crandall, The U.S. Steel Industry in Recurrent Crisis: Policy Options in a Competitive World (Brookings, 1981), chap. 5.

5. Ibid. 
by new filings of trade suits, and, finally, the abolition of the trigger price system. All these changes created enormous uncertainty among steel exporters.

In 1982, the EC agreed to limit steel exports to the United States in order to settle antidumping and countervailing duty cases brought by U.S. steel producers. Finally, in 1984, President Reagan announced a new set of voluntary restraints to end the Section 201 trade case brought by Bethlehem Steel earlier in the year. These new restraints, which were to include most steel exporting countries, limited finished steel imports to 18.5 percent of the U.S. market for 1985-89 and allowed the importation of another 1.5 million tons of semifinished steel. These restraints were not actually negotiated with most countries until mid-1985.

To place these three episodes of trade protection in perspective, it is useful to examine the trend in import penetration and to compare world export prices with realized U.S. prices during 1970-86 (see table 1). As the dollar rose after 1980, the share of imports in U.S. apparent consumption of steel rose with it. The sudden surge in 1984 was undoubtedly caused by exporters' anticipation that quotas to be negotiated in 1984-85 would be based on recent market shares.

The rising dollar and the EC settlement allowed U.S. producer prices to rise substantially above European spot prices in 1981-84, but this price difference has now begun to narrow with the declining dollar. The import share has fallen only modestly, but it remains at a historically high level despite the quotas. One may conclude, therefore, that threat of further trade restraints and the EC settlement allowed U.S. producers to keep their prices substantially above world levels through 1985, but the quotas negotiated in 1985 may have a much less restrictive effect at the current level of exchange rates.

\section{The Effectiveness of the Automobile Restraints}

The automobile restraints were directed solely at Japan. Beginning in April 1981, the Japanese were to limit their exports of passenger cars to the United States to 1.68 million units a year through March 31, 1984. In 1984 , the restraints were extended for one year at 1.85 million passenger cars, and in 1985 they were extended again for one year at 2.3 million units. In 1986, Japan's Ministry of International Trade and Industry 
Table 1. U.S. Steel Consumption, Imports, and Prices, 1970-86

Dollars per metric ton unless otherwise indicated

\begin{tabular}{lcccccc}
\hline & $\begin{array}{c}\text { Apparent } \\
\text { consumption } \\
\text { (millions } \\
\text { of tons) }\end{array}$ & $\begin{array}{c}\text { Imports } \\
\text { (millions } \\
\text { of tons) }\end{array}$ & $\begin{array}{c}\text { Import } \\
\text { share } \\
\text { (percent) }\end{array}$ & $\begin{array}{c}\text { U.S. } \\
\text { producers' } \\
\text { price }^{\mathrm{b}}\end{array}$ & $\begin{array}{c}\text { Antwerp } \\
\text { spot } \\
\text { export } \\
\text { price }^{\mathrm{c}}\end{array}$ & $\begin{array}{c}\text { U.S. price } \\
\text { minus } \\
\text { Antwerp } \\
\text { price }\end{array}$ \\
\hline 1970 & 97.1 & 13.4 & 13.8 & 149 & n.a. & $\ldots$ \\
1971 & 102.5 & 18.3 & 17.9 & 159 & n.a. & $\ldots$ \\
1972 & 106.6 & 17.7 & 16.6 & 169 & n.a. & $\ldots$. \\
1973 & 122.5 & 15.2 & 12.4 & 179 & 249 & -70 \\
1974 & 119.6 & 16.0 & 13.4 & 238 & 354 & -116 \\
1975 & 89.0 & 12.0 & 13.5 & 261 & 237 & 24 \\
1976 & 101.1 & 14.3 & 14.1 & 276 & 283 & -7 \\
1977 & 108.4 & 19.3 & 17.8 & 298 & 251 & 47 \\
1978 & 116.6 & 21.1 & 18.1 & 330 & 315 & 15 \\
1979 & 115.0 & 17.5 & 15.2 & 365 & 369 & -4 \\
1980 & 95.2 & 15.5 & 16.3 & 376 & 382 & -6 \\
1981 & 105.4 & 19.9 & 18.9 & 412 & 357 & 55 \\
1982 & 76.4 & 16.7 & 21.8 & 399 & 332 & 67 \\
1983 & 83.5 & 17.1 & 20.5 & 376 & 293 & 83 \\
1984 & 98.9 & 26.2 & 26.4 & 389 & 296 & 93 \\
1985 & 96.4 & 24.3 & 25.2 & 366 & 273 & 93 \\
1986 & 89.7 & 20.7 & 23.1 & $361^{\mathrm{d}}$ & 302 & 59 \\
\hline
\end{tabular}

Sources: Consumption and imports are from American Iron and Steel Institute, Annual Statistical Report, various years. Average prices are calculated by the author using data from U.S. Department of Commerce, Bureau of the Census, Steel Mill Products 1985, Current Industrial Reports, Series MA33B (Government Printing Office, 1986) and earlier issues; and Paine Webber, Inc., World Steel Dynamics: The Steel Strategist, various issues.

n.a. Not available.

a. Apparent consumption excludes changes in inventories.

b. Weighted average of the prices of six carbon steel categories, using 1979 shipment shares as weights.

c. Weighted average Free on Board (FOB) spot export price of six carbon steel products from Antwerp.

d. Author's estimate.

assumed unilateral responsibility for extending them at 2.3 million units a year-a decision reaffirmed this year for 1987-88.

The level of automobile imports in the 1980s suggests that the automobile restraints were much more effective than those on steel (table 2). With the dollar rising sharply between 1980 and 1984, the share of U.S. automobile sales accounted for by Japanese imports fell from 21.2 percent to 18.3 percent. The modest recovery in the Japanese import share since 1984 reflects the increase in the quota in April 1985.

Further evidence of the differences in effectiveness of the two voluntary restraint regimes may be found in the prices of Japanese imports and domestic automobiles. A simple model of the determinants of the price of a standardized mix of U.S. automobile imports from Japan 
Table 2. U.S. Automobile Sales and Import Shares, 1975-86

\begin{tabular}{cccc}
\hline & $\begin{array}{c}\text { Total } \\
\text { U.S. } \text { new } \\
\text { car sales } \\
\text { Year }\end{array}$ & \multicolumn{2}{c}{$\begin{array}{c}\text { Import share } \\
\text { (percent) }\end{array}$} \\
\cline { 2 - 4 } & (millions) & Total & From Japan \\
\hline 1975 & 8.63 & 18.2 & 9.4 \\
1976 & 10.10 & 14.8 & 9.3 \\
1977 & 11.18 & 18.5 & 12.4 \\
1978 & 11.31 & 17.7 & 12.0 \\
1979 & 10.64 & 21.9 & 16.6 \\
1980 & 8.98 & 26.7 & 21.2 \\
1981 & 8.53 & 27.3 & 21.8 \\
1982 & 7.98 & 27.9 & 22.6 \\
1983 & 9.18 & 26.0 & 20.9 \\
1984 & 10.39 & 23.5 & 18.3 \\
1985 & 11.04 & 25.7 & 20.1 \\
1986 & 11.45 & 28.3 & 20.7 \\
\hline
\end{tabular}

Sources: Motor Vehicle Manufacturers Association of the United States, MVMA Facts \& Figures, '86 (Detroit: MVMA, 1986), p. 16. Data for 1986 are taken from Automotive News, January 12, 1987, p. 42.

underpredicts 1984 prices by about $\$ 2,400$, an increase of $\$ 2,100$ from mid-1981. ${ }^{6}$ A comparison of the prices of two of the most popular small Japanese cars in the United States and Japan provides similar conclusions (table 3). By 1984-85, it appears that the restraints had become quite restrictive because of the sharp rise in the value of the dollar and the growth in U.S. automobile demand. A simple reaction function suggests that U.S. auto prices respond to import prices with an elasticity ranging from 0.3 to $0.4 .^{7}$ If this finding is correct, U.S. domestic car prices were $\$ 750$ to $\$ 1,000$ higher in $1984-85$ because of the quotas.

This estimate of the effects of the restraints on imported and domestic auto prices is substantially above others that have appeared in the literature, primarily because it adjusts for the effect of the yen and extends through 1984-85. Robert Feenstra, for example, has not explicitly allowed for the effects of the strong dollar in his estimates. ${ }^{8}$ Michael

6. The model uses Japanese wage rates, interest rates, steel prices, and the value of the yen to explain imported Japanese car prices over the period 1976-80. Robert W. Crandall, "The Effects of the Voluntary Export Agreement on U.S. Automobile Prices, 1981-84," paper presented at the annual meeting of the Society of Government Economists (December 1985).

7. Crandall, "The Effects of the Voluntary Export Agreement."

8. See, for example, Robert C. Feenstra, "Automobile Prices and Protection: The U.S.-Japan Trade Restraint," Journal of Policy Modelling, vol. 7 (Spring 1985), pp. 4968 . 
Table 3. The Effects of Voluntary Restraint Agreements on U.S. List Prices of Impurted Japanese Automobiles, 1980-85

Dollars per car

\begin{tabular}{|c|c|c|c|c|}
\hline \multirow[b]{2}{*}{ Year } & \multicolumn{2}{|c|}{ Prices } & \multirow[b]{2}{*}{ Difference } & \multirow{2}{*}{$\begin{array}{c}\text { Average } \\
\text { U.S.-Japanise } \\
\text { price } \\
\text { difference }\end{array}$} \\
\hline & Actual $^{\mathrm{a}}$ & Predicted $^{\mathbf{b}}$ & & \\
\hline 1980 & 5,976 & 6,228 & -252 & 518 \\
\hline 1981 & 7,077 & 6,786 & 291 & 1,312 \\
\hline 1982 & 7,766 & 7,414 & 352 & 2,428 \\
\hline 1983 & 7,960 & 6,257 & 1,703 & 2,862 \\
\hline 1984 & 8,501 & 6,110 & 2,391 & 2,972 \\
\hline 1985 & n.a. & n.a. & n.a. & 3,252 \\
\hline
\end{tabular}

Source: Author's calculations using data from World Cars, various issues.

n.a. Not available.

a. Average list price of U.S. automobile imports from Japan standardized for options loading and vehicle mix.

b. See text description and footnote 6 .

c. Average difference between list prices for two leading Japanese subcompact cars in the United States and Japan.

Bryan and Owen Humpage allow for currency effects, but their results extend only through $1983 .{ }^{9}$ The strong automobile market in 1984-85 allowed U.S. producers to realize prices far above those they could have sustained if there had been an elastic supply of Japanese imports at a price $\$ 2,500$ lower than the realized import price in $1984-85$. On the other hand, had the U.S. industry been competitive, the prices of imports and domestic cars would probably have risen far less in response to the restraints unless a capacity constraint had been binding. Because the domestic market is so concentrated, the restraints appear to have been a "facilitating" instrument in allowing output restraint among U.S. producers. ${ }^{10}$

As the dollar has fallen, the effect of the automobile restraints has diminished. The Japanese continue to limit their exports of automobiles to the United States to 2.3 million units, but a stagnating U.S. market, rising U.S. production of Japanese cars, and the 60 percent appreciation of the yen since 1984 has made the restraints largely irrelevant. Indeed, a recent analysis of U.S. and Japanese production costs suggests that

9. Michael F. Bryan and Owen F. Humpage, "Voluntary Export Restraints: The Cost of Building Walls," Economic Review (Federal Reserve Bank of Cleveland, Summer 1984), pp. 17-37.

10. Kala Krishna, "Trade Restrictions as Facilitating Practices," Working Paper 1546 (National Bureau of Economic Research, January 1985). 
Table 4. U.S. Steel Industry Profits and Investment, 1970-85

Billions of 1967 dollars

\begin{tabular}{rrc}
\hline Year & Profits & Investment \\
\hline 1970 & 0.50 & 1.41 \\
1971 & 0.51 & 1.03 \\
1972 & 0.68 & 0.83 \\
1973 & 1.05 & 0.93 \\
1974 & 1.84 & 1.34 \\
1975 & 1.09 & 1.83 \\
1976 & 0.86 & 1.74 \\
1977 & 0.01 & 1.50 \\
1978 & 0.71 & 1.25 \\
1979 & 0.62 & 1.42 \\
1980 & 0.77 & 1.39 \\
1981 & 1.16 & 1.28 \\
1982 & -1.38 & 1.30 \\
1983 & -1.48 & 1.13 \\
1984 & -0.10 & 1.23 \\
1985 & -0.46 & 1.43
\end{tabular}

Sources: Total profits of U.S. steel companies are from AISI, Annual Statistical Report, various years, adjusted by author for nonreporting companies and deflated by the overall consumer price index from the Economic Report of the President, 1987, table B-55. Investment is new plant and equipment expenditures from Survey of Current Business, vol. 66 (February 1986), deflated by the implicit price deflator for total private nonresidential investment from Economic Report of the President, 1987, table B-3, rebased to 1967.

unit costs are equalized in the auto industry at about 150 yen to the dollar, or very close to the dollar's value in early $1987 .{ }^{11}$

\section{The Impact of Import Restraints on Investment and Profits}

The express rationale of the trade restraints for both autos and steel is to give each industry breathing room to reassert its competitiveness through investment and cost cutting. The 1970s restraints and the 197880 trigger prices may have enhanced U.S. steel producers' profits marginally and in so doing may have stimulated investment either by increasing expected future profitability or through increased cash flow. Real steel industry profits rose in 1978-81, aided by the falling dollar in 1978-79 and by the trigger prices. Since 1981, however, the industry has been earning negative real profits (table 4). Real investment in steel has

11. Clifford Winston and Associates, Blind Intersection? Policy and the Automobile Industry (Brookings, 1987), pp. 19-20. 
Table 5. Modernization, Capacity Reductions, and the Return on Common Equities in the Steel Industry

\begin{tabular}{|c|c|c|c|}
\hline Company & $\begin{array}{c}\text { Annual } \\
\text { investment, } \\
1975-81, \\
\text { as a fraction } \\
\text { of } 1975 \\
\text { market value }\end{array}$ & $\begin{array}{c}\text { Market return } \\
\text { on owning } \\
\text { equity, } \\
1982-86^{\mathrm{b}}\end{array}$ & $\begin{array}{c}\text { Percentage change } \\
\text { in capacity, } \\
1981-86^{\mathrm{c}}\end{array}$ \\
\hline Sharon & 0.264 & -0.962 & -30.6 \\
\hline Wheeling-Pittsburgh & 0.235 & -0.746 & -38.6 \\
\hline $\operatorname{LTV}^{d}$ & 0.214 & -0.894 & -46.3 \\
\hline Kaiser & 0.191 & Bankrupt & -100.0 \\
\hline CF\&I & 0.177 & -0.901 & -68.4 \\
\hline Bethlehem & 0.165 & -0.691 & -27.6 \\
\hline Inland & 0.160 & -0.093 & -30.1 \\
\hline National & 0.140 & -0.330 & -54.7 \\
\hline Armco & 0.092 & -0.791 & -28.7 \\
\hline U.S. Steel & 0.076 & -0.081 & -23.0 \\
\hline Interlake & 0.069 & 0.449 & -33.3 \\
\hline
\end{tabular}

Source: Author's calculations using annual reports of the above listed companies and U.S. Securities and Exchange Commission (Forms 10-K, Annual Report), various years.

a. Average annual value of real plant and equipment expenditures in steel, 1975-81, divided by value of firm on December 31, 1975 (defined as market value of equity plus book value of long-term debt).

b. Cumulative return from holding a share of equity in the firm from January 1, 1982, through December 31, 1986.

c. Percentage change in raw steel capacity, 1981 to 1986.

d. Includes Republic Steel.

shown little trend since 1977 despite the trade restraints that have been in place for most of the period.

But if protection had been effective in raising industry cash flows substantially, and if, for some reason, these additional cash flows or enhanced profit margins had been successful in generating greater investment outlays, the industry would actually be worse off than it is.

Beginning in the early 1970s, the U.S. integrated industry could not profitably invest in major facilities. ${ }^{12}$ High construction costs, rapidly changing minimill technology, and stagnating steel demand created an environment in which the incremental returns to investment in huge blast furnaces, steel furnaces, and rolling mills were insufficient to cover the cost of capital. Those firms that invested most intensively in modernizing and rounding out their plants during 1975-81, after the large rise in steel prices in 1974, generally suffered the largest losses in market value during the next five years (table 5). Of the top five firms, ranked by investment rate, four have begun bankruptcy proceedings, and one

12. Crandall, The U.S. Steel Industry, chap. 4. 
Table 6. U.S. Motor Vehicle Factory Sales, Profits, and Investments, 1970-85

\begin{tabular}{lcccc}
\hline Year & $\begin{array}{c}\text { Factory } \\
\text { sales } \\
\text { (millions) }\end{array}$ & $\begin{array}{c}\text { Profit per } \\
\text { vehicle } \\
\text { (1967 dollars) }\end{array}$ & $\begin{array}{c}\text { Cash flow } \\
\text { per vehicle } \\
\text { (1967 dollars) }\end{array}$ & $\begin{array}{c}\text { Real } \\
\text { investment } \\
\text { (billions of } \\
\text { 1967 dollars) }\end{array}$ \\
\hline 1970 & 8.2 & 128 & 397 & 2.63 \\
1971 & 10.6 & 391 & 564 & 1.96 \\
1972 & 11.3 & 418 & 595 & 2.32 \\
1973 & 12.6 & 345 & 499 & 2.86 \\
1974 & 10.1 & 47 & 242 & 2.93 \\
1975 & 9.0 & 138 & 359 & 1.99 \\
1976 & 11.5 & 368 & 536 & 2.01 \\
1977 & 12.6 & 410 & 588 & 3.03 \\
1978 & 12.9 & 354 & 545 & 3.47 \\
1979 & 11.5 & 181 & 398 & 3.67 \\
1980 & 8.1 & -126 & 191 & 3.66 \\
1981 & 8.0 & 5 & 323 & 3.71 \\
1982 & 7.0 & 22 & 359 & 2.72 \\
1983 & 9.2 & 271 & 589 & 2.50 \\
1984 & 10.7 & 301 & 586 & 3.90 \\
1985 & 11.4 & 185 & 432 & 5.07 \\
\hline
\end{tabular}

Sources: Based on data from the following sources: MVMA, MVMA Facts and Figures, '86; U.S. Department of Commerce, Bureau of Economic Analysis, The National Income and Product Accounts of the United States, 192982 Statistical Tables (GPO, 1986); Survey of Current Business, vol. 66 (July 1986); and the Economic Report of the President, 1987.

a. Profits before taxes, with inventory valuation adjustment, deflated by the consumer price index and divided by total U.S. vehicle factory sales.

b. Profits before taxes with inventory valuation adjustment plus capital consumption allowance, deflated by the consumer price index and divided by total U.S. vehicle factory sales.

c. Investment expenditures in standard industrial classification 371 deflated by the implicit price deflator for nonresidential investment, rebased to 1967.

has abandoned all integrated steel facilities. Of the bottom five, only Armco has shown a large loss in market value-because it diversified unsuccessfully into financial services. Thus, to the extent that protection stabilized or raised prices and contributed to the excessive optimism among steelmakers in the mid-1970s, it proved to be extremely counterproductive.

In the automobile industry, real profits have risen steadily since 1982 despite sharply lower domestic sales of vehicles. Profits per unit in 198385 were nearly 40 percent above those in 1974-76, when industry output was similar but the dollar was 30 percent lower (table 6). Real investment lagged its late 1970s levels until 1984, when it rose sharply, aided somewhat by Japanese investment in the U.S. automobile industry.

The restraints produced an estimated increase in cash flow of some 
$\$ 6-\$ 8$ billion, before leakages into other factor suppliers' rents. ${ }^{13}$ Thus, between 33 and 45 percent of the 1984-85 auto industry cash flow may be attributed to the restraints, even assuming no effect upon unit sales. This large increment of cash flow, or the analogous rise in profit margins, may have had some effect upon 1985-86 industry investment outlays.

\section{The Response of Labor Costs, Productivity, and Product Quality}

Because import restraints reduced competitive pressure from abroad and raised industry prices and profits, they also influenced industry wage bargains. This section examines the trends in labor costs and productivity during the 1970s and 1980s.

\section{WAGES}

The steel industry's total compensation first accelerated in the early 1970 s with the first restraints and rose rapidly in the late 1970s with the trigger price system (table 7). ${ }^{14}$ Since 1982, a year in which average wages rose sharply because of massive layoffs of low-seniority and therefore lower-wage workers, total compensation in the steel industry has fallen, reflecting the declining condition of the industry. Because the 1984 restraints have not had a major effect upon steel prices or profits, they have not been able to stem the decay of real wages in the industry. Moreover, the rise in the minimill share of the industry has brought additional downward pressure on union wages at the integrated companies. ${ }^{15}$

In the automobile industry, compensation generally tracked steel compensation until steel wages began their sharp increase in the early

13. This assumes no increase in U.S. output due to the quotas. For a discussion of the output effects, see Winston and Associates, Blind Intersection?, pp. 64-65.

14. In the early 1970 s, the industry reached an "experimental negotiating agreement" with the United Steelworkers of America that guaranteed the workers at least 3 percent increases in real wages each year in return for an agreement not to strike. Such an agreement on the part of management presumably reflected its confidence that price competition from imports would not be a major problem.

15. Since 1975 , minimill shipments have risen more rapidly than imports. See Donald F. Barnett and Robert W. Crandall, Up from the Ashes: The Rise of the Steel Minimill in the United States (Brookings, 1987). 
Table 7. Average Hourly Compensation for Production Workers in the Auto Industry, Steel Industry, and All Manufacturing, 1970-85

Dollars

\begin{tabular}{lccccc}
\hline Year & $\begin{array}{c}\text { All manu- } \\
\text { facturing }\end{array}$ & $\begin{array}{c}\text { Motor } \\
\text { vehicles }\end{array}$ & $\begin{array}{c}\text { Ratio to } \\
\text { manufactur- } \\
\text { ing average }\end{array}$ & Steel & $\begin{array}{c}\text { Ratio to } \\
\text { manufactur- } \\
\text { ing average }\end{array}$ \\
\hline 1970 & 4.18 & 5.65 & 1.35 & 5.74 & 1.37 \\
1971 & 4.49 & 6.45 & 1.44 & 6.24 & 1.39 \\
1972 & 4.84 & 7.03 & 1.45 & 7.08 & 1.46 \\
1973 & 5.26 & 7.51 & 1.43 & 7.76 & 1.48 \\
1974 & 5.75 & 8.34 & 1.45 & 8.88 & 1.54 \\
1975 & 6.35 & 9.53 & 1.50 & 10.24 & 1.61 \\
1976 & 6.92 & 10.08 & 1.46 & 11.23 & 1.62 \\
1977 & 7.59 & 11.22 & 1.48 & 12.31 & 1.62 \\
1978 & 8.27 & 12.37 & 1.50 & 13.56 & 1.64 \\
1979 & 9.00 & 13.43 & 1.49 & 15.15 & 1.68 \\
1980 & 9.80 & 15.88 & 1.62 & 17.46 & 1.78 \\
1981 & 10.79 & 16.94 & 1.57 & 19.04 & 1.76 \\
1982 & 11.50 & 17.99 & 1.56 & 22.72 & 1.98 \\
1983 & 11.97 & 18.23 & 1.52 & 21.14 & 1.77 \\
1984 & 12.40 & 18.92 & 1.53 & 20.26 & 1.63 \\
1985 & 12.82 & 19.73 & 1.54 & 21.45 & 1.67 \\
Percentage change & & & & & \\
$1970-75$ & 51.9 & 68.7 & $\ldots$ & 78.4 & $\ldots$ \\
$1975-80$ & 54.3 & 66.6 & $\ldots$ & 70.5 & $\ldots$ \\
$1981-85$ & 18.8 & 16.5 & $\ldots$ & 12.7 & $\ldots$ \\
\hline
\end{tabular}

Source: U.S. Department of Labor, Bureau of Labor Statistics, Office of Productivity and Technology.

1970s (table 7). Binding protection in the 1980s has allowed the autoworkers to resist wage reductions more successfully than the steelworkers and to maintain their premium over average manufacturing compensation at about 55 percent in the early 1980 s, or about 6 percentage points above the late 1970s premium. Ford and General Motors were forced to award fairly generous settlements in their 1984 wage negotiations, returning a large share of the concessions negotiated during the 1981-82 recession, because of their large quota-induced profits.

As these wage developments suggest, given the substantial role of labor costs in both industries, effective trade protection simply postpones part of the necessary adjustment to the loss of competitiveness. The steel industry today is paying for wage increases granted behind a 
protective barrier in the $1970 \mathrm{~s},{ }^{16}$ and U.S. automobile producers may face further competitive difficulties because of their continuing wage escalation.

\section{PRODUCTIVITY}

Since 1980, labor productivity in steel and motor vehicles has accelerated sharply. Average annual percentage increases are shown below for five-year intervals since 1965:

$\begin{array}{ccc} & \text { Steel } & \begin{array}{c}\text { Motor } \\ \text { vehicles }\end{array} \\ 1965-70 & 0.0 & 0.5 \\ 1970-75 & 1.3 & 4.4 \\ 1975-80 & 2.0 & 0.7 \\ 1980-85 & 5.9 & 6.0\end{array}$

Upon closer inspection, however, it is difficult to conclude that the improvement has been due to trade protection. Rather, it has been caused by a cyclical rebound and capacity retirement. A simple regression analysis of labor productivity in the motor vehicle industry (all employees) from 1960 to 1985 reveals that the automobile quotas had no effect upon 1981-85 productivity. (Here and elsewhere the numbers in parentheses are $t$-statistics.)

$$
\begin{aligned}
\log P R O D= & 2.74+0.285 \log C A P U T I L \\
& +0.031 \text { TIME } \\
& -0.008 \text { DQUOTA }, \\
& (-0.37) \\
\bar{R}^{2}= & 0.985 ; \text { Durbin-Watson }=1.77 ; \text { rho }=0.223 .
\end{aligned}
$$

Equation 1 shows the results of regressing the logarithm of labor productivity $(\log P R O D)$ on the Federal Reserve Board estimate of industry capacity utilization $(\log C A P U T I L)$, a time trend (TIME), and a dummy variable (DQUOTA) for the voluntary restraint period,

16. See Colin Lawrence and Robert Z. Lawrence, "Manufacturing Wage Dispersion: An End Game Interpretation," BPEA, 1:1985, pp. 47-106, for a discussion of steel wages in recent years. 
1981-85. The coefficient of DQUOTA suggests that none of the recent increase in productivity can be assigned to the quotas. Nor does this conclusion change for the period 1984-85. Effects of the 1984-85 investment surge on productivity cannot be ascertained yet from available data.

A somewhat different analysis of steel productivity is required. Between 1981 and 1985, the steel industry retired nearly 30 million tons of extremely inefficient integrated capacity. The retirement program, by itself, should have raised average industry productivity substantially, accounting for a large share of the startling rebound since 1980 . To account for this, a separate variable for industry capacity $(\log C A P A C I T Y)$ is included as a shift variable in equation 2 , estimated for the period 1962 to 1985 :

$$
\begin{aligned}
\log P R O D= & 9.46+0.366 \log C A P U T I L+0.020 \text { TIME } \\
& (12.77)(8.14) \quad(20.31) \\
& -1.37 \log C A P A C I T Y, \\
& (-8.90) \\
\bar{R}^{2}= & 0.951 ; \text { Durbin-Watson }=2.03 ; \text { rho }=0.225 .
\end{aligned}
$$

As expected, the capacity variable proves to be important in explaining the recent rise in productivity. Moreover, the residuals from equation 2 show no positive tendency in the 1980 s, suggesting that the targeting of investment on modernizing a smaller capacity has had little effect upon productivity.

\section{PRODUCT QUALITY}

In recent years, U.S. producers of both steel and automobiles have fallen behind their Japanese counterparts in product quality. The recent decline of the dollar has reduced their production cost disadvantages, but if U.S. producers continue to lag in product quality they may still find it difficult to compete with imports and with products produced by foreigners on U.S. soil.

Among the most important indexes of product quality in automobiles is reliability in use. Data on repair frequencies show that during the mid1970s, the Big Three U.S. producers saw their product reliability decline 
Table 8. Repair Frequency for U.S. Automobile Producers, Relative to Japanese Producers, Model Years 1975-85

\begin{tabular}{cccc}
\hline $\begin{array}{c}\text { Model } \\
\text { year }\end{array}$ & $\begin{array}{c}\text { General } \\
\text { Motors }\end{array}$ & Ford & Chrysler \\
\hline 1975 & 1.86 & 1.62 & 2.47 \\
1976 & 1.90 & 1.67 & 2.78 \\
1977 & 1.42 & 1.33 & 2.77 \\
1978 & 1.60 & 1.55 & 2.80 \\
1979 & 2.29 & 2.38 & 2.69 \\
1980 & 2.89 & 2.30 & 2.40 \\
1981 & 3.32 & 2.12 & 3.45 \\
1982 & 3.12 & 1.44 & 2.26 \\
1983 & 2.82 & 1.74 & 2.89 \\
1984 & 2.80 & 2.10 & 3.33 \\
1985 & 2.59 & 1.89 & 2.22 \\
\hline
\end{tabular}

Source: Based on Consumer Reports, various April issues.

a. Simple unweighted average repair frequency rating for each company's most recent models minus the average for all Japanese models based on the following scale: $1=$ much better than average; $2=$ better than average; $3=$ average; $4=$ worse than average; $5=$ much worse than average.

substantially relative to the Japanese (table 8). A simple regression analysis of these reliability gaps shows that Ford and Chrysler reduced their substantial disadvantage relative to the Japanese on average by approximately 20 percent in $1981-85$ and that this reduction is statistically significant. General Motors, by contrast, failed to make statistically significant progress and now has the widest quality gap of the major domestic producers.

In the steel industry, a spate of joint ventures with Japanese companies has permitted the U.S. integrated companies to offer quality galvanized steel for automotive applications. But older rolling mills and raw steel facilities are still less able to provide quality products than the facilities of many foreign competitors.

\section{Lessons for Policy}

Concern over the ability of U.S. industries to compete in unrestrained international markets has once again raised protectionist sentiment among U.S. lawmakers. In the past, the stated objectives of import quotas or voluntary import restraints was to provide temporary insulation from international competition to allow particularly hard-hit indus- 
tries the opportunity to regain market shares. The experience with the auto and steel industries raises serious questions about the effectiveness of quotas as a means to revitalize an industry.

\section{STEEL}

Despite the trade protection of the late 1970s and 1980s, the integrated steelmakers were forced to launch a major retrenchment in the early 1980s. These companies began closing plants, reducing capacity from 138 million tons in 1980 to 90 million tons in 1987. By the late 1990s, integrated steelmaking capacity is likely to decline by another 25-30 million tons. With only a few exceptions, high construction costs and high steelworker wage rates have made investment in large-scale integrated capacity an uneconomic proposition since 1970. During the mid1970s, the American Iron and Steel Institute, and presumably most of its members, predicted steel demand levels for the mid-1980s that were as much as 50 percent too high. As a result, these companies overinvested during the mid- and late 1970s. In 1975, the companies expected to need 30 million additional tons of capacity; in fact, they have actually retired more than 50 million tons of their 1975 capacity.

The smaller minimills have increased their capacity from 10 million tons in 1975 to 25 million tons at present and are likely to have at least 35 million tons by the mid-1990s. ${ }^{17}$ These smaller companies will continue to invade the large companies' markets because of recent changes in technology and the minimills' lower labor and materials costs. Sending market signals to the integrated firms in the mid-1970s to expand and modernize capacity in the 1970 s would have been (and perhaps was) a serious error.

It is unfortunate that much of recent steel policy has been based upon a premise that more investment is required to make the industry healthy. Tying reinvestment of earnings in steel to trade protection in the 1984 Steel Import Stabilization Act is the most recent example of this error. It is bad enough to base trade restrictions upon faulty economic premises; it is even worst to derive further conditionality from these same premises.

17. Barnett and Crandall, Up from the Ashes. 


\section{AUTOMOBILES}

The situation for the automobile industry was not as desperate as that for steel in the 1980s, though without trade protection, Chrysler may have failed, and industry profits would have been extremely low throughout the first half of the 1980s. The voluntary restraints added substantially to automobile company cash flows, but they may not have raised output or employment. Indeed, Winston and his associates find that the restraints raised domestic prices and increased cash flow more than $\$ 8$ billion per year, but actually reduced industry output 3-4 percent in 1983-84. ${ }^{18}$

The welfare cost of the restraints, according to Winston and his associates, was $\$ 5$ billion to the U.S. economy in 1984 , and as much as $\$ 2$ billion for the United States and Japan combined. ${ }^{19}$ That cost peaked in 1984-85 and has fallen substantially since with the decline in the dollar. Had protection been offered in the form of a declining temporary tariff, rather than binding quotas, the U.S. price response may have been lower and the welfare loss to the U.S. economy, less.

Because the restraints allowed the United Auto Workers to maintain their premium over other manufacturing wages and even raise it above its late 1970s level, any cost improvements due to the quotas would have to be due to their effect upon investment and the resultant increases in productivity. Capital investment in the motor vehicle industry accelerated in 1984-85, perhaps in response to the profits derived from quotas. But I can detect no improvement in productivity and only limited progress in U.S. product quality relative to Japanese models.

Another indirect effect of the automobile restraints may prove to be their most lasting benefit. As a result of the restraints, several Japanese companies accelerated plans to build assembly plants in the United States by two to four years. Table 9 lists three plants that are now operating and four that are either under construction or in the planning stages. Of these, only the Honda plant was under development before the restraints were negotiated in 1981 . Still, it seems unlikely that

18. Winston and Associates, Blind Intersection?, pp. 64-65.

19. Three billion dollars of the U.S. welfare loss is transfers to the Japanese automobile industry, its factor suppliers, and dealers. 
Table 9. Japanese Investment in U.S. Automobile Assembly Plants, Various Years, 1982-89

\begin{tabular}{lcc}
\hline \multicolumn{1}{c}{ Plant and location } & $\begin{array}{c}\text { Annual capacity } \\
\text { (number } \\
\text { of cars) }\end{array}$ & $\begin{array}{c}\text { Start-up } \\
\text { date }\end{array}$ \\
\hline Honda (Marysville, Ohio) & 360,000 & 1982 \\
Nissan (Smyrna, Tennessee) & $240,000^{\mathrm{a}}$ & 1985 \\
Toyota-General Motors (Fremont, California) & 250,000 & 1984 \\
Mazda (Flat Rock, Michigan) & 240,000 & 1987 \\
Mitsubishi-Chrysler (Bloomington-Normal, Illinois) & 240,000 & 1988 \\
Toyota (Georgetown, Kentucky) & 200,000 & 1988 \\
Fuji-Isuzu (Lafayette, Indiana) & 120,000 & 1989 \\
\hline
\end{tabular}

Source: Japan Economic Institute, "The U.S. Automobile Parts Market and Japanese Competition," JEI Report 11A (March 20, 1987), table 4.

a. Including pickup trucks.

accelerating the start-up of these plants-amassing a total capacity of 1.29 million cars-could be worth more than a fraction of the $\$ 10-\$ 15$ billion welfare loss absorbed by U.S. consumers in 1982-85.

Perhaps the greatest error in the protection of U.S. automobiles has been the choice of instrument. The rigid quotas on Japanese imports have allowed a very concentrated industry to restrain output and raise price. The resulting U.S. economic welfare losses are unlikely to be recouped through productivity and quality improvements by U.S. producers, but the benefits of accelerating the Japanese investment in U.S. automobile production facilities may prove to be substantial. In the end, it is new competition, not the restriction of competition, that will revitalize the U.S. automobile industry. 